\title{
Potential Role of Cropping System and Integrated Nutrient Management on Nutrients Uptake and Utilization by Maize Grown in Calcareous Soil
}

\author{
Mostafa Mohamed Selim \\ Department of Field Crops Research, Agricultural Division, National Research \\ Centre, Dokki, Cairo, Egypt.
}

\begin{abstract}
$\mathbf{H}$ IGH concentration of $\mathrm{CaCO}_{3}, \mathrm{pH}$ and $\mathrm{EC}$, are among the main constraints affecting soil health, nutrients solubility, availability and lower productivity. Managing agronomic practices are the best way for insuring soil deterioration. Field experiments, in split plot design, were carried out in two summer seasons of 2017 and 2018 years at Nobaria, Behaira Governorate, Egypt, to investigate the effect of cropping systems and nutrients management on the nutrients uptake and utilize by maize (Zea mays L.). The experiment included three intercropping systems viz., sole maize ; cereal/cereal and cereal/legume and four fertilization treatments viz., recommended dose of NPK (control); half of recommended dose; half of recommended dose+organic manure (compost) $30 \mathrm{~m}^{3} \mathrm{ha}^{-1}$ and half of recommended dose+organic manure (compost) $30 \mathrm{~m}^{3} \mathrm{ha}^{-1}+$ inoculation seeds with multi strains microbial bacteria. Results confirmed that maize/legumes intercropped resulted in superior nutrients uptake and robust improvements in yield advantages. Additionally, intercropped maize/legumes and application the half dose of the recommended chemical fertilizers alongside $30 \mathrm{~m}^{3} \mathrm{ha}^{-1}$ of organic manure and seed inoculation with bacteria could mitigate soil nutrients deficiency, increased $\mathrm{N}, \mathrm{P}, \mathrm{K}$ and remaining an increase of final grain yields by $14.47 \%$ and $26.41 \%$ in both seasons, respectively. While, maize/cereal intercropped increased the uptake of Fe, Mn and $\mathrm{Zn}$. Results highlighted that intercropping systems alongside integrated nutrients management could compensate the reduced dose of synthetic fertilizers. Such practices are the most effective practices can prevent nutrients deficiency and help small householder farmers to achieve high yield.
\end{abstract}

Keywords: Intercropping pattern, Organic-inorganic fertilizers, Integrated nutrients, Maize cowpea/millet, Calcareous soils.

\section{Inroduction}

Recently, much higher nutrient outflows due to some bad practices followed by farmer's viz., intensive agriculture, neglected cropping sequences and ignored fertilization programs; all these among the factors of soil degradation are the main challenges facing improving agriculture. Thus, low priority is given to increasing the current productivity to meet the present rapid population growth and changing in food preferences, as well as decreasing the gap between total food production and human consumption. Nutrient managements are therefore, a vital component of agriculture strategy plan to 2050. Although, the extension of the cultivated area is an urgent priority for increasing national income, regretfully the most of the allowed lands for reclamation are sandy or sandy calcareous soils contains relatively high amounts of calcium trioxocarbonate $\left(\mathrm{CaCO}_{3}\right)$, very low in organic matter, higher EC and alkaline $\mathrm{pH}$ that pronounced influence on nitrogen $(\mathrm{N})$ loss and or fixation, reduce the solubility and availability of phosphorus (P) and potassium (K).Under such condition, most of nutrients required for crop growth and productivity are frequently limited. Numerous of researches, $\mathrm{Mc}$ Dowell et al. (2008), Boschetti et al. (2009) and Marschner (2012) suggested that acidification and alkalization in the rhizosphere are the dominant factors affecting soil nutrients solubility and availability (Fig. 1). For example, in alkaline soils where higher $\mathrm{pH}$ are prevailing, marked decrease in $\mathrm{Fe}, \mathrm{Zn}, \mathrm{Mn}$ and $\mathrm{Cu}$ absorption were observed, because of these elements are highly correlated to lower pH (Kaya et al., 2009; Haigang et al., 2010; Motior Rahman et al., 2011 and Marschner, 2012).

Corresponding author emails: selim family@hotmail.com DOI: 10.21608 /agro.2018.6277.1134 


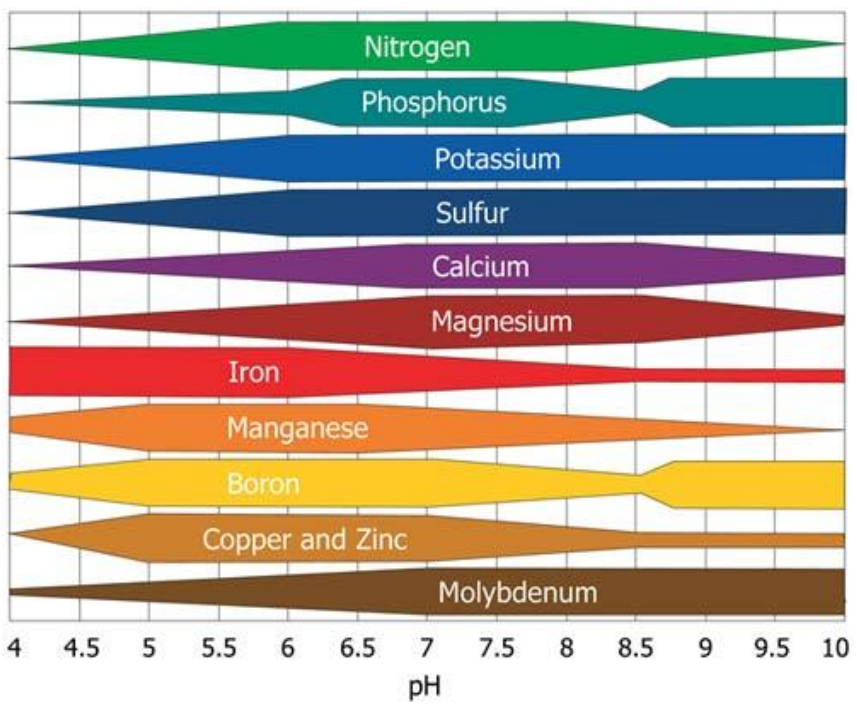

Fig1. Relative availability of plant nutrients by soil pH. (Truog, 1946)

Farmers are full dependence on application of chemical fertilizers to obtained yield performance, which is not neither economical nor pragmatic practice, due to the prices of most fertilizers always are not fixed and sometimes are not available for poor farmers. Furthermore, many farmers and agriculture specialists are not believed that they can obtain economic yield without application of fertilizers. Nevertheless, a higher amount of fertilizers are required to sustain the same yields in the second and third seasons as compared to the first one, since two to three crops are grown annually (Kacar \& Katkat, 2009). Certainly, continuous use of huge amounts of inorganic fertilizers is the main reason of vastly deteriorating soil health, productivity and both stability and sustainability. As stated by Yolcu et al. (2011) and Recep İrfan et al. (2015), overuse of inorganic fertilizers leading to problems of nutrient deficiency, environmental pollution and damages soil chemical properties through increasing soil acidity, and leading to decrease both crop yield and quality. So, the attention has changed directly towards organic sources (Suge et al., 2011; Gudugi, 2013 and Ghulam et al., 2015).

Earlier, farmers have recognized that, application of organic manure is an urgent priority for restoring soil health and improving soil physical, chemical and biological properties, particularly in arid and semi-arid soils, which are already suffered from the limitations and unavailability of essential nutrients (Adeoye et al., 2011; Siavoshi et al., 2011; Rahmann et al., 2016 and Selim \& Alowayed, 2017). Several studies for long-time experiments at farmers fields are worthy cleared that, minerals uptake and subsequently yield of many crops were much higher, when application of organic fertilizers in combination with synthetic fertilizers (Integrated nutrients management), in the recommended dose or with a partial dose from the recommended, compared to control (Sarwar et al., 2007 and 2008). The efficiency of the usages of organic manures in combination with synthetic fertilizers can be explained by the solitary role of each one as well as their combination in improving soil physiochemical properties, optimizing $\mathrm{pH}$, EC values, alleviating the absence of essential nutrients in poor soils and regulation the relationship between plant absorption and soil nutrient contents (Bhattacharyya et al., 2007; Tewolde et al., 2007; Kaya et al., 2009 and Marschner, 2012). Nonetheless, knowledge of the optimum combination of organic with inorganic fertilizers, which can be compensate the reduce dose of chemical fertilizers and the time of application also are necessary for activating the economic use of fertilizers and to obtain maximum yield of high quality traits (Suge et al., 2011; Ghulam et al., 2015 and Selim \& Al-Owied, 2017).

Intercropping is one of a multiple cropping system, which has a good utilization of ecological 
resources, such as solar radiation, water, soil area and fertilizers for ensuring yield advantages ( $\mathrm{Li}$ et al., 2013 and 2014). Also, intercropping may be the lonely choice or the dominant option must be done, for example the area under agroforestry (Zomer et al., 2009). Among the different cropping systems, the popular option in intercropping is legume/cereal (Midega et al., 2014). Several studies Wu et al. (2012), Qin et al. (2013), Liu et al. (2017) and Wang et al. (2017b), suggested that the yield advantages of intercropping over sole cropping system are due to more than one reason, such as different plant species grown in the same time in the same area, are need different nutrient requirements, thus reducing competition between neighboring plants and gave chance to complementary use of environmental resources viz., nutrients; water and light. In the same context, previously some studies suggested that, yield advantages in term of intercropping system may be due to increasing the mobility, releasing and uptake of nutrients such as $\mathrm{Fe}, \mathrm{N}$, and $\mathrm{P}$ (Haigang et al., 2010; Li et al., 2011 and Paltridge et al., 2014) or increasing land use efficiency (land equivalent ratio, LER) and nutrients utilization (Li et al., 2011) and light (Mao et al., 2014) and enhanced positive interactions relationship between neighboring crops ( $\mathrm{Lv}$ et al., 2014 and Jannoura et al., 2014). Furthermore, Qin et al. (2013) stated that, the success of intercropping systems may be due to the improving in utilization of available environmental resources. In addition, the study of Kimou et al. (2017) revealed that there were significant effects of intercropping systems on growth and yield components of maize and cowpea than mono-cropping pattern; they also revealed that greatest productivity per unit area was achieved by intercropping two crops together. However, intercropping system offers low cost, pragmatic and a sustainable solution to nutrients deficiency in marginal soils. Also, intercropping system can play a vital role in global agricultural economy (FAO, 2012).

Although, intercropping system is a complex field practices and need more labors, which resulting higher labor costs, but its gains in long run to the soil improvements are more than expended (Caviglia et al., 2011). Sometimes, intercropping systems are facing by much stress, leading to low crop productivity including both biotic components (plants, animals, fungi and bacteria) and abiotic components (chemical and physical elements such as soil minerals, sunlight, moisture, and temperature). Iqbal et al. (2012) and Rahman et al. (2013), suggested that accepting intercropping systems inside bio-organic farming in poor soil fertility and or in inadequate nutrient supplies can successfully compensate to the low productivity. In the same context, the experiments of Chandrakala et al. (2017) concluded that adopting such agronomic practices alongside integrated nutrient management practices could supplies plant for long time with its nutrients requirement and thereby overcome the serious problems of excessive applications of $\mathrm{N}$ and $\mathrm{P}$ fertilizers.

Bio-fortification is a ecofriendly practice, offers rhizosphere with sustainable microbial community structure, delivers a viable solution to most of macro and micronutrients deficiency, also can reduce the dose of inorganic fertilizer, creates favorable soil physiochemical conditions, environmental health and sustaining economic yield (Song et al., 2007; Garbeva et al., 2008; Samreen et al., 2017 and Wang et al., 2017a).

Keeping the view of the previous literature, although realizing some advantages by following some agronomic practices and nutrients management, we are still need knowledge about the approach which can be achieved higher yield and sustain soil health. Therefore, the purpose of the current study is to overcome the problems of nutrients deficit and attaining higher yield with higher quality traits of maize grown in calcareous soils by using agronomic practices and nutrients management.

\section{Materials and Methods}

Description of the experimental site

Field experiments were conducted at Experimental Farm of the Production Sector, Ministry of Agriculture, Nobaria District, Behaira Governorate, the location is about $35 \mathrm{~km}$ from Alexandria city and about $13 \mathrm{~km}$ east of Alexandria desert road, $\left(30^{\circ} 91 \mathrm{~N}\right.$ latitude, $29^{\circ} 96 \mathrm{E}$ longitude and almost at analtitude of $14 \mathrm{~m}$ above the sea). The total annual rainfall is very little, only in November, December, January and very rarer in February, average amount of annual rainfall amounted $154 \mathrm{~mm}$ and the average temperature during the growth period was $29.0^{\circ} \mathrm{C}-32.8^{\circ} \mathrm{C}$ (Max.) and $20.5^{\circ} \mathrm{C}-22.8^{\circ} \mathrm{C}$ and the average temperature was $24.7^{\circ} \mathrm{C}-26.8^{\circ} \mathrm{C}$. 


\section{Plant material}

Seeds selected plant species were used in the present study are Maize (Zea mais L.) c.v Giza 310 and cowpea (Vigna unguiculata L. Walp.) c.v Giza 3 and pearl millet (Pennisetum glaucum L.) c.v Shandaweel 1. All seeds were obtained from Agriculture Research Center (ARC), Field Crops Research Institute, Giza, Egypt.

\section{Organic manure}

the organic manure which was used in the present study is resulting from decomposting different types of agriculture wastes mixed with cow manure and microbial activators with $\left(1 \times 10^{8}\right)$ of each of Streptomycs aurefaciens, Trichoderma viridie, T. harzianum, Bacillus subtilis and B. licheniformis (1L/ton) aerobically in heaps, then nearly after four months the mixture will turned into a good quality, brown to dark brown humidified, more stable in form and valuable source of plant nutrients (compost).

\section{Seed inoculation}

Before sowing seeds were inoculated with $\mathrm{N}$-fixing bacteria (Azotobacter) and phosphate dissolving bacteria (Pseudomonas sp.)

Soil chemical analyses

At the start of the experiment and before commencement field preparation, eight soil samples were collected from three depths $0-25$, 25-70 and $70-120 \mathrm{~cm}$ layers for determining some physical and chemical properties. Samples were sent to National Research Centre laboratory for measuring chemical analyses. Samples were dried and ground to pass a $2 \mathrm{~mm}$ sieve. The soil electrical conductivity in saturated paste (EC e) was measured using the method as outlined by Janzen (1993). Soil pH was determined in a 1:2.5 $(\mathrm{w} / \mathrm{v})$ soil/water suspension using a $\mathrm{pH}$ meter with a glass electrode. The total $\mathrm{N}$ concentration was determined by the Dumas method (Bremner, 1996) and available $P$ was extracted by the Mehlich 1 method (Donohue et al., 1983). Phosphorus was determined calorimetrically using the ammonium molybdate-ascorbic acid method, and $\mathrm{K}$ was measured by atomic absorption spectroscopy (Donohue et al., 1983). Soil organic-matter content was determined only in samples from $0-25 \mathrm{~cm}$ deep by the WalkleyBlack titration method (Nelson \& Sommers, 1982). All concentrations were expressed on an oven-dried-weight basis. Also available micronutrients were also determined according to the methods described by (Cottenie, 1982; But, 2004). Results are presented in Tables 1, 2 and 3.

TABLE 1. Mean of physical properties of the soil site samples.

\begin{tabular}{|c|c|c|c|c|c|c|c|c|c|c|c|}
\hline Properties & $\begin{array}{c}\text { Saturation } \\
\%\end{array}$ & $\begin{array}{c}\text { pH soil } \\
\text { paste } \\
(1: 2.5)\end{array}$ & $\begin{array}{c}E C \\
(\mathrm{dS} / \mathrm{m})\end{array}$ & $\begin{array}{c}\text { O.M } \\
\%\end{array}$ & $\begin{array}{c}\mathrm{CaCO}_{3} \\
\%\end{array}$ & $\begin{array}{c}\text { Field } \\
\text { capacity } \\
(\%)\end{array}$ & $\begin{array}{c}\text { Wilting } \\
\text { point } \\
(\%)\end{array}$ & $\begin{array}{c}\text { Sand } \\
(\%)\end{array}$ & $\begin{array}{l}\text { Silt } \\
(\%)\end{array}$ & $\begin{array}{l}\text { Clay } \\
(\%)\end{array}$ & $\begin{array}{c}\text { Soil texture } \\
(\%)\end{array}$ \\
\hline First season & 29.70 & 8.21 & 2.98 & 0.42 & 29.62 & 16.30 & 7.67 & 57.92 & 27.20 & 14.88 & Sandy loam \\
\hline Second season & 28.12 & 7.98 & 2.81 & 0.48 & 29.43 & 16.42 & 7.71 & 57.82 & 27.25 & 14.90 & Sandy loam \\
\hline
\end{tabular}

TABLE 2. Mean of chemical properties of the soil profile samples.

\begin{tabular}{|c|c|c|c|c|c|c|c|c|c|c|c|c|}
\hline \multirow{2}{*}{$\begin{array}{l}\text { Active } \\
\mathrm{CaCO}_{3} \%\end{array}$} & \multirow{2}{*}{$\begin{array}{c}\text { Total } \\
\mathrm{CaCO}_{3} \%\end{array}$} & \multicolumn{3}{|c|}{ Soluble anions (meq/L) } & \multicolumn{4}{|c|}{ Soluble cations (meq/L) } & \multirow{2}{*}{$\begin{array}{c}\text { E.C } \\
\text { dS/m } \\
\text { (paste) }\end{array}$} & \multirow{2}{*}{$\begin{array}{c}\text { pH } \\
\text { soil paste } \\
1: 2.5\end{array}$} & \multirow{2}{*}{$\begin{array}{l}\text { SP } \\
\%\end{array}$} & \multirow{2}{*}{$\begin{array}{c}\text { Depth } \\
\text { (cm) }\end{array}$} \\
\hline & & $\mathrm{SO}_{4}{ }^{=}$ & $\mathrm{Cl}^{-}$ & $\begin{array}{c}\mathrm{CO}_{3}^{--} \\
+\mathrm{HCO}^{-}\end{array}$ & $\mathbf{K}^{+}$ & $\mathbf{N a}^{+}$ & $\mathbf{M g}^{++}$ & $\mathrm{Ca}^{++}$ & & & & \\
\hline 7.0 & 18.46 & 18.7 & 23.5 & 1.2 & 2.0 & 22.4 & 7.9 & 11.1 & 4.34 & 8.30 & 53.3 & $0-25$ \\
\hline 13.5 & 30.77 & 12.4 & 22.9 & 1.0 & 1.7 & 16.9 & 7.2 & 10.5 & 3.63 & 8.20 & 48.3 & $25-70$ \\
\hline 14.0 & 34.62 & 9.8 & 14.3 & 0.9 & 1.2 & 9.7 & 6.0 & 8.1 & 2.50 & 8.17 & 50.0 & $70-120$ \\
\hline
\end{tabular}

TABLE 3. Mean of available nutrients in initial samples of the experimental soil site.

\begin{tabular}{lccccccc}
\hline $\begin{array}{l}\text { Depth } \\
(\mathbf{c m})\end{array}$ & $\begin{array}{c}\text { Total } \\
\mathbf{N \%}\end{array}$ & $\begin{array}{c}\text { Available } \\
\mathbf{( P )} \mathbf{p p m}\end{array}$ & $\begin{array}{c}\text { Available } \\
\mathbf{K}(\mathbf{p p m})\end{array}$ & $\begin{array}{c}\text { Available } \\
\mathbf{F e}(\mathbf{p p m})\end{array}$ & $\begin{array}{c}\text { Available } \\
\text { Mn (ppm) }\end{array}$ & $\begin{array}{c}\text { Available } \\
\text { Zn (ppm) }\end{array}$ & $\begin{array}{c}\text { O.M } \\
\mathbf{\%}\end{array}$ \\
\hline $0-25$ & 0.15 & 2.5 & 223.5 & 2.6 & 3.9 & 1.5 & 1.7 \\
\hline
\end{tabular}




\section{Treatments details and experimental design}

The experimental treatments were distributed in a split-plot design based on randomized complete block design with four replications. The main plots contained cropping systems, which are included, common sowing practice throughout the studied area (sole sowing maize); intercropping maize with millet and intercropping maize with cowpea in intercropping system by alternating two rows of maize were intercropped with two rows of either cereal (pearl millet) or legume (cowpea) $(2 \mathrm{M}: 2 \mathrm{C}: 2 \mathrm{M})$. Whereas, fertilization treatments included four treatments were occupied subplots. Treatments details are presented in Table 4. Chemical composition of the manure (compost) used in the experiments are presented in Table $4 \mathrm{~b}$.

TABLE 4a. The fertilization treatments details.

\begin{tabular}{ll}
\hline $\begin{array}{c}\text { Treatment } \\
\text { No. }\end{array}$ & \multicolumn{2}{c}{ Detail } \\
\hline F1 & $\begin{array}{l}\text { Recommended dose of chemical } \\
\text { fertilizers NPK. }\end{array}$ \\
F2 & $\begin{array}{l}\text { Half of the recommended dose of } \\
\text { chemical fertilizers. }\end{array}$ \\
F3 & $\begin{array}{l}\text { Half of the recommended dose of } \\
\text { chemical fertilizers+organic manure } \\
\text { (compost) } 30 \mathrm{~m}^{3} \mathrm{ha}^{-1} .\end{array}$ \\
F4 & $\begin{array}{l}\text { Half of the recommended dose of } \\
\text { chemical fertilizers+organic manure } \\
\text { (compost) } 30 \mathrm{~m}^{3} \text { ha }{ }^{-1}+\text { seed inoculation } \\
\text { with multi strains bacteria (Biofertilizers). }\end{array}$ \\
\hline
\end{tabular}

TABLE $4 \mathrm{~b}$. Chemical composition of compost used.

\begin{tabular}{lc}
\hline Characters & Value \\
\hline Organic carbon $(\%)$ & 13.0 \\
E.C. $\mathrm{dSm}^{-1}$ & 2.47 \\
$\mathrm{pH}$ & 7.76 \\
Total N (\%) & 0.60 \\
Available P $\left(\mathrm{mg} \mathrm{kg}^{-1}\right)$ & 84.5 \\
C/N ratio & 21.8 \\
\hline
\end{tabular}

\section{Crop management}

\section{Field preparation and sowing}

Two weeks before sowing, soil sites were prepared as recommended, i.e. soil ploughing three cross harrowing's, then properly leveled ridges and divided into plots. Each plot included six ridges, six meters length and $60 \mathrm{~cm}$ apart; total experimental unit area was $21.60 \mathrm{~m}^{2}$ to avoid the effect of lateral movement of irrigation water and soluble nutrients, the plots were isolated by borders of $1.5 \mathrm{~m}$ in width from each side. Recommended dose of chemical fertilizers of NPK viz., phosphorus fertilizer at the rate of $90 \mathrm{~kg} \mathrm{P}_{2} \mathrm{O}_{5} \mathrm{ha}^{-1}$ as the form of superphosphate $\left(\begin{array}{lll}16 \% & \mathrm{P}_{2} \mathrm{O}_{5}\end{array}\right)$ and potassium as the form of potassium sulphate $\left(42 \% \mathrm{~K}_{2} \mathrm{O}\right)$, by the rate of $100 \mathrm{~kg} \mathrm{~K}_{2} \mathrm{O} \mathrm{ha}^{-1}$ were applied broadcasting and mixed with soil, to plots which receive full doses of chemical fertilizers (control) and also to the plots which included the half dose of the recommended dose of chemical fertilizers, the half dose of each elements was applied. Whereas, nitrogen fertilizer was applied in splitting dose two times, once after thinning and the second 45 days later, according to the experimental details (full dose of the recommended $150 \mathrm{~kg} \mathrm{~N} \mathrm{ha}^{-1}$ or the half dose of the recommended $75 \mathrm{~kg} \mathrm{~N} \mathrm{ha}^{-1}$ ). Organic manure (compost) was also applied by the rate of $30 \mathrm{~m}^{3} \mathrm{ha}^{-1}$ according to the treatment details. Before sowing, seeds of the crop in the treatment which included biofertilizers were treated with an adhesive material (Arabic gum) to make the seed surface sticky, immediately mixed with multiple strains bacterial (mixture of nitrogen fixer bacteria and phosphate dissolving bacteria (PDB, Pseudomonas sp.), by the rate of $8 \mathrm{~g}$ per $\mathrm{kg}$ seed. Sowing maize was done on $14^{\text {th }}$ and $16^{\text {th }}$ April in the first and second seasons, respectively. The presiding crop was wheat in both seasons. Two weeks earlier cowpea was sown in the assigned two ridges in 2 drills/ ridge at the plant density of $350 \times 10^{3}$. In the same times seeds of millet were also sown in hills $15 \mathrm{~cm}$ spaced. Two weeks later maize was sown in hills $20 \mathrm{~cm}$ spaced on both sides. After 21 days from sowing, plants were thinned to two plants per hill 20 days after sowing. Irrigation water was performed as followed by farmers in the experimental site area.

\section{Data recorded}

Measuring yield and yield component characters: At harvest, two ridges were hand pulled and biological yield per hectare were determined. Sub sample of ten border plants was taken and completely air dried and then ear cover was pulled, and yield component characters were determined viz., ear length $(\mathrm{cm})$, ear weight $(\mathrm{g})$, seed weight per ear $(\mathrm{g})$ and hundred seed weight (g) were determined. Seed yield $\left(\mathrm{kg} \mathrm{ha}^{-1}\right)$ was also calculated.

Plant chemical analyses: Representative samples of the plant were taken at maximum growth stages after 90 days from sowing, and 
sent to National Research Centre laboratory for measuring chemical analyses. Samples were washed with distilled water, oven dried at $72^{\circ} \mathrm{C}$ for $48 \mathrm{~h}$ and grounded to powder in a ball mill. Then, plant samples were digested by the dry ashing method (Jones \& Case, 1990) for determining total $\mathrm{N}$ by Kjeldahl's method by digesting the contents in $\mathrm{H}_{2} \mathrm{SO}_{4}$ followed by distillation (Jones \& Case, 1990). Phosphorus and $\mathrm{K}$ were determined by digesting the samples in 1:5 $\mathrm{HClO}_{4}: \mathrm{HNO}_{3}$ mixture. The digests were analyzed for $\mathrm{P}$ by vandomolybdo phosphoric acid yellow color method (Cottenie, 1982) and $\mathrm{K}$ by emission spectroscopy. Total content of micronutrients (Fe, Mn and $\mathrm{Zn}$ ) using spectroscopy methods) described by Donohue \& Aho (1992).
Statistical analyses

Data were statistically analyzed using analyses of variance appropriate for split plot design as described by Gomez \& Gomez (1984). Means were compared using new least significant differences (LSD) test at 0.05 level of probability.

\section{Results}

Yield and yield components characters, nutrients uptake by maize in different cropping systems, fertilization treatments as well as their combinations in two cropping seasons in calcareous soil were investigated in the current study, in order to overcome the problem of nutrients deficiency. Results given are presented in Tables 5, 6, 7, 8, 9 and 10 .

TABLE 5. Mean of yield and yield component characters of intercropped maize in response to nutrient managements as well as their interactions (first season).

\begin{tabular}{|c|c|c|c|c|c|c|c|c|c|}
\hline $\begin{array}{l}\text { Cropping } \\
\text { system }\end{array}$ & $\begin{array}{c}\text { Fertilization } \\
\text { treatments }\end{array}$ & $\begin{array}{c}\text { Plant } \\
\text { height } \\
(\mathrm{cm})\end{array}$ & $\begin{array}{c}\text { Ear } \\
\text { length, } \\
\text { (cm) }\end{array}$ & $\begin{array}{c}\text { No. of } \\
\text { rows } \\
\text { ear }^{-1}\end{array}$ & $\begin{array}{c}\text { Grain } \\
\text { yield ear-1 } \\
\text { (g) }\end{array}$ & $\begin{array}{l}\text { Hundred } \\
\text { grains } \\
\text { weight (g) }\end{array}$ & $\begin{array}{c}\text { Biological } \\
\text { yield, } \\
\left(\text { ton } \mathrm{ha}^{-1}\right)\end{array}$ & $\begin{array}{c}\text { Grain yield } \\
\left(\text { ton } h^{-1}\right)\end{array}$ & $\begin{array}{c}\text { Harvest } \\
\text { index } \\
\%\end{array}$ \\
\hline \multirow{4}{*}{ Maize Solid* } & F1 & 211.3 & 19.3 & 13.20 & 278.2 & 24.28 & 18.75 & 7.275 & 38.80 \\
\hline & $\mathrm{F} 2$ & 200.0 & 18.7 & 13.00 & 242.7 & 22.87 & 18.22 & 7.220 & 39.63 \\
\hline & F3 & 212.8 & 19.8 & 13.20 & 276.6 & 23.84 & 19.60 & 7.789 & 39.74 \\
\hline & F4 & 213.6 & 19.9 & 13.35 & 295.5 & 25.26 & 19.82 & 7.885 & 39.78 \\
\hline \multicolumn{2}{|c|}{ General mean of solid } & 209.4 & 19.4 & 13.19 & 272.8 & 24.56 & 19.10 & 7.542 & 39.49 \\
\hline \multirow{4}{*}{ Cereal/ cereal } & F1 & 212.3 & 19.6 & 13.40 & 291.4 & 25.42 & $18 . .60$ & 7.408 & 39.83 \\
\hline & $\mathrm{F} 2$ & 206.0 & 19.2 & 12.91 & 255.6 & 23.86 & 18.64 & 7.410 & 39.75 \\
\hline & F3 & 212.7 & 19.4 & 13.48 & 284.2 & 26.38 & 18.80 & 7.575 & 40.29 \\
\hline & $\mathrm{F} 4$ & 215.6 & 20.8 & 13.38 & 289.9 & 27.82 & 19.46 & 7.736 & 39.75 \\
\hline \multicolumn{2}{|l|}{ General mean } & 211.7 & 19.8 & 13.29 & 279.8 & 26.37 & 18.88 & 7.532 & 39.91 \\
\hline \multirow{4}{*}{ Cereal/legume } & F1 & 214.0 & 20.9 & 13.75 & 298.7 & 25.83 & 19.12 & 7.678 & 40.16 \\
\hline & $\mathrm{F} 2$ & 212.8 & 20.4 & 13.39 & 272.8 & 23.80 & $18 . .87$ & 7.677 & 40.68 \\
\hline & F3 & 218.7 & 20.2 & 13.70 & 291.4 & 27.25 & 19.53 & 7.831 & 40.10 \\
\hline & F4 & 235.7 & 21.4 & 14.88 & 336.2 & 29.83 & 20.23 & 8.298 & 41.03 \\
\hline \multicolumn{2}{|c|}{ General mean } & 220.3 & 20.7 & 13.93 & 299.3 & 26.68 & 19.46 & 7.871 & 40.51 \\
\hline \multicolumn{10}{|c|}{ LSD at 0.05 level for: } \\
\hline \multicolumn{2}{|c|}{ Cropping system } & 7.6 & 0.71 & 0.54 & 5.48 & 0.22 & 0.18 & 0.312 & ----- \\
\hline \multicolumn{2}{|c|}{ Interaction } & 4.3 & 0.24 & 0.39 & 27.5 & 1.82 & 0.25 & 0.152 & ------ \\
\hline
\end{tabular}

TABLE 6. Mean of yield and yield component characters of intercropped maize in response to nutrient managements (first season).

\begin{tabular}{|c|c|c|c|c|c|c|c|c|}
\hline $\begin{array}{l}\text { Fertilization } \\
\text { treatment }\end{array}$ & $\begin{array}{l}\text { Plant height } \\
\text { (cm) }\end{array}$ & $\begin{array}{l}\text { Ear length } \\
\quad(\mathrm{cm})\end{array}$ & $\begin{array}{c}\text { No. of } \\
\text { rows ear }{ }^{-1}\end{array}$ & $\begin{array}{c}\text { Grain yield } \\
\text { ear-1 }^{-1} \\
\text { (g) }\end{array}$ & $\begin{array}{c}\text { Hundred } \\
\text { grains } \\
\text { weight (g) }\end{array}$ & $\begin{array}{c}\text { Biological } \\
\text { yield } \\
\left(\text { ton } \text { ha }^{-1}\right)\end{array}$ & $\begin{array}{c}\text { Grain } \\
\text { yield } \\
\left(\text { ton } \text { ha }^{-1}\right)\end{array}$ & $\begin{array}{c}\text { Harvest } \\
\text { index } \\
\%\end{array}$ \\
\hline F1 & 212.53 & 19.93 & 13.45 & 289.4 & 25.18 & 18.82 & 7.435 & 39.60 \\
\hline $\mathrm{F} 2$ & 206.27 & 19.43 & 13.10 & 257.3 & 23.51 & 18.58 & 7.625 & 39.85 \\
\hline F3 & 214.73 & 19.80 & 13.46 & 284.6 & 25.82 & 19.31 & 7.732 & 40.04 \\
\hline F4 & 221.63 & 20.70 & 13.87 & 307.2 & 27.64 & 19.84 & 7.973 & 40.19 \\
\hline LSD at 0.05 level & 5.46 & 0.22 & 0.31 & 22.7 & 1.18 & 0.44 & 0.271 & ---- \\
\hline
\end{tabular}


TABLE 7. Mean of yield and yield component characters of intercropped maize in response to nutrient managements as well as their interactions (second season).

\begin{tabular}{|c|c|c|c|c|c|c|c|c|c|}
\hline $\begin{array}{l}\text { Cropping } \\
\text { system }\end{array}$ & $\begin{array}{c}\text { Fertilization } \\
\text { treatments }\end{array}$ & $\begin{array}{c}\text { Plant } \\
\text { height } \\
(\mathrm{cm})\end{array}$ & $\begin{array}{l}\text { Ear length } \\
\quad(\mathrm{cm})\end{array}$ & $\begin{array}{c}\text { No. of } \\
\text { rows } \\
\text { ear }^{-1} \\
\end{array}$ & $\begin{array}{c}\text { Grain } \\
\text { yield ear }^{-1} \\
(\mathrm{~g})\end{array}$ & $\begin{array}{c}\text { Hundred } \\
\text { grain } \\
\text { weight (g) }\end{array}$ & $\begin{array}{c}\text { Biological } \\
\text { yield } \\
\left(\text { ton } \text { ha }^{-1}\right)\end{array}$ & $\begin{array}{c}\text { Grain } \\
\text { yield } \\
\left(\text { ton } \mathbf{h a}^{-1}\right)\end{array}$ & $\begin{array}{c}\text { Harves } \\
\text { index } \\
\% \\
\end{array}$ \\
\hline \multirow{4}{*}{ Maize solid ${ }^{*}$} & F1 & 213.8 & 19.70 & 13.30 & 280.9 & 24.59 & 20.10 & 7.818 & 38.90 \\
\hline & $\mathrm{F} 2$ & 209.2 & 18.90 & 13.10 & 244.2 & 23.08 & 19.04 & 6.969 & 36.60 \\
\hline & F3 & 223.9 & 19.85 & 13.30 & 275.8 & 23.91 & 20.69 & 7.760 & 37.51 \\
\hline & $\mathrm{F} 4$ & 240.6 & 20.20 & 13.74 & 301.5 & 25.92 & 22.83 & 8.943 & 39.18 \\
\hline \multicolumn{2}{|c|}{ General mean of solid } & 220.9 & 19.66 & 13.36 & 275.6 & 24.38 & 20.67 & 7.873 & 38.05 \\
\hline \multirow{4}{*}{ Cereal/cereal } & $\mathrm{F} 1$ & 212.8 & 19.20 & 13.52 & 288.8 & 25.26 & 19.78 & 7.880 & 39.83 \\
\hline & $\mathrm{F} 2$ & 212.6 & 18.00 & 13.40 & 261.4 & 23.92 & 19.03 & 7.127 & 37.45 \\
\hline & F3 & 229.8 & 19.50 & 13.80 & 283.2 & 25.21 & 19.81 & 7.703 & 36.93 \\
\hline & F4 & 230.9 & 20.80 & 13.96 & 306.5 & 25.97 & 20.86 & 7.922 & 39.98 \\
\hline \multicolumn{2}{|l|}{ General mean } & 221.5 & 19.88 & 13.67 & 284.9 & 25.09 & 19.87 & 7.658 & 38.55 \\
\hline \multirow{4}{*}{ Cereal/legume } & F1 & 220.6 & 20.30 & 13.65 & 298.5 & 26.32 & 19.28 & 7.145 & 38.09 \\
\hline & $\mathrm{F} 2$ & 223.9 & 20.00 & 13.58 & 279.7 & 24.79 & 19.13 & 7.147 & 37.46 \\
\hline & F3 & 242.9 & 21.60 & 14.22 & 300.0 & 26.90 & 21.97 & 8.250 & 37.55 \\
\hline & $\mathrm{F} 4$ & 254.5 & 21.40 & 14.83 & 314.5 & 27.68 & 24.28 & 9.883 & 40.71 \\
\hline General mean & & 235.5 & 20.83 & 14.07 & 298.2 & 26.42 & 21.67 & 8.356 & 38.50 \\
\hline \multicolumn{10}{|c|}{ LSD at 0.05 level for: } \\
\hline \multicolumn{2}{|c|}{ Cropping system } & 12.9 & 1.32 & 0.35 & 8.12 & 1.23 & 0.79 & 0.121 & - \\
\hline \multicolumn{2}{|c|}{ Interaction } & 4.2 & 0.15 & 0.42 & 12.4 & 1.26 & 0.68 & 0.894 & - \\
\hline
\end{tabular}

TABLE 8. Mean of yield and yield component characters of intercropped maize in response to nutrient managements (second season).

\begin{tabular}{lcccccccc}
\hline $\begin{array}{l}\text { Fertilization } \\
\text { treatment }\end{array}$ & $\begin{array}{c}\text { Plant height Ear length } \\
(\mathbf{c m})\end{array}$ & $\begin{array}{c}\text { No. of } \\
\text { (cm) }\end{array}$ & $\begin{array}{c}\text { Grain yield } \\
\text { ear }^{-1}\end{array}$ & $\begin{array}{c}\text { Hundred } \\
\text { (g) }\end{array}$ & $\begin{array}{c}\text { Brain weight } \\
\text { (g) }\end{array}$ & $\begin{array}{c}\text { Biegical } \\
\text { yield } \\
\left(\text { ton ha }^{-1}\right)\end{array}$ & $\begin{array}{c}\text { Grain } \\
\text { yield } \\
\left(\text { ton ha }^{-1}\right)\end{array}$ & $\begin{array}{c}\text { Harvest } \\
\text { index } \\
\text { \% }\end{array}$ \\
\hline F1 & 215.7 & 19.73 & 13.49 & 289.4 & 25.39 & 20.39 & 7.948 & 39.00 \\
F2 & 215.2 & 18.97 & 13.36 & 261.8 & 23.93 & 19.87 & 7.081 & 37.17 \\
F3 & 232.2 & 20.32 & 13.77 & 286.3 & 25.34 & 20.82 & 7.904 & 37.33 \\
F4 & 242.0 & 20.80 & 14.18 & 302.7 & 26.52 & 22.66 & 8.916 & 39.96 \\
\hline LSD at 0.05 level & 8.72 & 0.48 & 0.28 & 12.9 & 1.12 & 1.22 & 0.68 & - \\
\hline
\end{tabular}

TABLE 9. Mean of N, P, K, Fe, Zn and Mn uptake by maize plant as affected cropping systems and fertilization treatments under calcareous soil (data mean of two seasons).

\begin{tabular}{|c|c|c|c|c|c|c|c|}
\hline \multirow{2}{*}{$\begin{array}{l}\text { Cropping } \\
\text { system }\end{array}$} & \multirow{2}{*}{ Fertilization } & \multicolumn{3}{|c|}{ Macronutrients uptake $\left(\mathrm{kg} \mathrm{ha}^{-1}\right)$} & \multicolumn{3}{|c|}{ Micronutrients uptake (g ha-1) } \\
\hline & & $\mathbf{N}$ & $\mathbf{P}$ & K & $\mathrm{Fe}$ & Zn & Mn \\
\hline \multirow{4}{*}{ Solid } & F1 & 245.5 & 39.5 & 213.5 & 1.844 & 1.239 & 1.199 \\
\hline & $\mathrm{F} 2$ & 255.3 & 26.4 & 185.3 & 1.108 & 1.122 & 1.231 \\
\hline & F3 & 308.0 & 44.5 & 211.3 & 2.115 & 1.442 & 1.224 \\
\hline & F4 & 321.6 & 48.9 & 232.0 & 2.387 & 1.572 & 1.345 \\
\hline \multicolumn{2}{|c|}{ General mean of solid } & 282.6 & 39.1 & 210.5 & 1.864 & 1.344 & 1.250 \\
\hline \multirow{4}{*}{ Cereal/cereal } & $\mathrm{F} 1$ & 233.5 & 36.0 & 199.8 & 2.092 & 1.464 & 1.397 \\
\hline & $\mathrm{F} 2$ & 212.2 & 25.6 & 177.2 & 1.754 & 1.312 & 1.115 \\
\hline & F3 & 289.8 & 40.3 & 217.0 & 2.285 & 1.668 & 1.423 \\
\hline & F4 & 290.4 & 44.5 & 220.5 & 2.445 & 1.792 & 1.642 \\
\hline \multicolumn{2}{|l|}{ General mean } & 256.5 & 36.6 & 203.6 & 2.144 & 1.559 & 1.390 \\
\hline \multirow{4}{*}{ Cereal/legume } & F1 & 292.5 & 38.0 & 234.0 & 1.756 & 1.160 & 1.128 \\
\hline & $\mathrm{F} 2$ & 246.5 & 27.8 & 212.6 & 1.485 & 1.112 & 1.101 \\
\hline & F3 & 315.5 & 45.6 & 238.5 & 1.988 & 1.104 & 1.266 \\
\hline & F4 & 338.5 & 52.5 & 243.2 & 1.992 & 1.198 & 1.321 \\
\hline General mean & & 298.3 & 41.0 & 232.1 & 1.805 & 1.144 & 1.204 \\
\hline \multicolumn{8}{|c|}{ LSD at 0.05 level for : } \\
\hline \multicolumn{2}{|c|}{ Cropping system } & 7.6 & 2.4 & 5.6 & 0.192 & 0.158 & 0.120 \\
\hline \multicolumn{2}{|c|}{ Interaction } & 4.2 & 1.3 & 3.4 & 0.177 & 0.085 & 0.142 \\
\hline
\end{tabular}


TABLE 10. Mean of N, P, K, Fe, $\mathrm{Zn}$ and Mn uptake by maize plant as affected cropping systems and fertilization treatments under calcareous soil (data mean of two seasons).

\begin{tabular}{lcccccc}
\hline \multirow{2}{*}{ Fertilization } & \multicolumn{3}{c}{ Macronutrients uptake $\left(\mathbf{k g ~ h a}^{-1}\right)$} & \multicolumn{3}{c}{ Micronutrients uptake $\left(\mathbf{g ~ h a}^{-1}\right)$} \\
\cline { 2 - 7 } & $\mathbf{N}$ & $\mathbf{P}$ & $\mathbf{K}$ & $\mathbf{F e}$ & $\mathbf{Z n}$ & Mn \\
\hline F1 & 257.2 & 37.8 & 215.8 & 1.897 & 1.288 & 1.241 \\
F2 & 238.0 & 26.6 & 191.7 & 1.449 & 1.182 & 1.149 \\
F3 & 304.4 & 43.5 & 222.3 & 2.129 & 1.405 & 1.304 \\
F4 & 316.8 & 48.6 & 231.9 & 2.275 & 1.521 & 1.436 \\
\hline LSD at 0.05 level: & 14.2 & 4.7 & 5.8 & 0.124 & 0.112 & 0.121 \\
\hline
\end{tabular}

Effect of cropping systems, integrated nutrients management and their interactions on the yield and yield components of maize in two cropping seasons

Compared to the tested cropping systems, results presented in Tables 5 and 7 revealed that intercropped maize with either cowpea or millet surpassed sole sowing maize. However, intercropped maize-cowpea exceeded maizemillet and recorded the tallest maize height $(220.3 \mathrm{~cm}$ and $235.5 \mathrm{~cm}$.), in the first and second seasons, respectively as compared to intercropped maize-millet, which registered $(211.7 \mathrm{~cm}$ and $221.5 \mathrm{~cm})$, in the first and second seasons, respectively. Whereas, the lowest plant height $(209.4 \mathrm{~cm}$ and $220.9 \mathrm{~cm})$ were recorded with mono cropping system in the first and second season, respectively. Regarding, yield and yield component characters, it is worthy note that the highest values of ear length $(20.70 \mathrm{~cm}$ and $20.83 \mathrm{~cm})$; number of rows per ear (13.93 and 14.07); grain yield per ear (299.3g and $314.50 \mathrm{~g})$; hundred seeds weight $(26.68 \mathrm{~g}$ and $26.42 \mathrm{~g})$; biological yield (ton ha-1) (19.46 and 21.67); grain yield (ton ha-1) (7.871 and 8.356) and harvest index $(40.51 \%$ and $38.50 \%)$ were recorded with sowing maize in intercropping system with cowpea, in the first and second seasons, respectively. Followed by intercropped maize with millet recorded higher values, compared to sole sowing in most of yield component characters, except biological yield ton $\mathrm{ha}^{-1}$ and grain yield ton ha ${ }^{-1}$, sole maize sowing exceeded intercropped maize/millet, in the first and second seasons, respectively.

Likened to nutrients managements, data recorded in Table 6 and 8 cleared that, the tallest maize plants $(221.63 \mathrm{~cm}$ and $242.0 \mathrm{~cm})$, in the first and second seasons, respectively were found in the treatment, which received the half dose of chemical fertilizers+organic manure (compost) $30 \mathrm{~m}^{3} \mathrm{ha}^{-1}+$ Biofertilizers (F4). In the same tables, the treatment received full dose of chemical fertilizers (F1) registered plant height $(212.53 \mathrm{~cm}$ and $215.70 \mathrm{~cm})$. As a results registered in the same table, treatment which received the half dose of chemical fertilizers (F2), recorded the shortest plant height $(206.27 \mathrm{~cm}$. and $215.2 \mathrm{~cm})$. However, application the half dose of chemical fertilizers in combination with organic manure (compost) $30 \mathrm{~m}^{3} \mathrm{ha}^{-1}(\mathrm{~F} 3)$, recorded plant height $(214.73 \mathrm{~cm}$. and $232.2 \mathrm{~cm}$.), in the first and second seasons, respectively. Likewise, the highest values of yield and yield component characters viz., ear length $(20.70 \mathrm{~cm}$. and $20.80 \mathrm{~cm}$.); number of rows per ear (13.87 and 14.18); grain yield per ear (307.2g and $302.7 \mathrm{~g})$; hundred seeds weight $(27.64 \mathrm{~g}$ and $26.52 \mathrm{~g}$ ); biological yield (ton $\mathrm{ha}^{-1}$ ) (19.84 and 22.66); grain yield (ton ha $\left.{ }^{-1}\right)(7.973$ and 8.916) and harvest index $(40.19 \%$ and $39.96 \%)$, were accompanying the treatment which received the half dose of chemical fertilizers+organic manure (compost) $30 \mathrm{~m}^{3} \mathrm{ha}^{-1}+$ Biofertilizers (F4), in the first and second seasons, respectively. Contrary, the lowest values of the same parameters were obtained from the treatment, which received sole application of half dose of chemical fertilizers (F2). Nonetheless, application the half dose of chemical fertilizers in combination with either organic manure $30 \mathrm{~m}^{3} \mathrm{ha}^{-1}$ or biofertilizers (F3 and F4), the picture was changed and an increase in grain yield (ton ha ${ }^{-1}$ ) amounted $(1.40 \%$ and $4.56 \%)$ and (11.62\% and $25.91 \%)$, were recorded in the first and second seasons, respectively.

As a result of the solitary effect of cropping systems and nutrients management, a significant positive interactive effect on most of yield and yield component characters were also found. Plots of intercropped maize with cowpea and received the half dose of chemical fertilizers+organic manure $30 \mathrm{~m}^{3} \mathrm{ha}^{-1}+$ biofertilizers (F4) exceeding all tested treatments and recorded the highest values of plant height $(235.7 \mathrm{~cm}$. and $254.5 \mathrm{~cm}$.), in the first 
and second seasons, respectively. Furthermore, data in the same tables, also revealed that the same treatment (F4), recorded the highest values of ear length $(21.4 \mathrm{~cm}$ and $21.40 \mathrm{~cm})$; number of rows per ear (14.88 and 14.83); grain yield per ear $(336.2 \mathrm{~g}$ and $314.5 \mathrm{~g}) ; 100$ grain weight (29.83 g and $27.68 \mathrm{~g})$; biological yield $\left(\mathrm{ha}^{-1}\right)$ (20.23ton and 24.28ton); harvest index (41.03\% and $40.71 \%$ ) and final grain yield ton $\mathrm{ha}^{-1}$ (8.328ton and 9.883ton), the increment in final grain yield amounted $(14.47 \%$ and $26.41 \%)$, as compared to the treatment of sowing maize solid and application the full dose of chemical fertilizer, in the first and second seasons, respectively. Such effect of the interaction was expected early since the sole effect of each factor was significant and recorded the highest values of most of yield and yield component characters in both seasons.

Effect of cropping systems, nutrients management and their interactions on nutrients uptake by maize in two cropping seasons

Regarding nutrients uptake by maize grown in calcareous soil under different cropping systems, nutrients management as well as their interactions. Data registered in Table 9, worthy cleared that among intercropping systems, maize/ legume intercropping performed better nutrients absorption as compared to cereal/cereal or sole cropping systems in terms of nitrogen, phosphorus and potassium uptake. However the picture was changed in the uptake of micro-nutrients Fe, $\mathrm{Zn}$ and $\mathrm{Mn}$, however maize/legume intercropping pattern recorded the lowest values. Regarding the effect of managing nutrients application, it is notably that application of the half dose of recommended chemical fertilizers+organic manure $30 \mathrm{~m}^{3} \mathrm{ha}^{-1}+$ Biofertilizers (F4), recorded the highest values of N, P, K, Fe, Zn and Mn uptake by maize than the other treatments (Table 10). In the same table the lowest values were registered by application the half dose of the recommended chemical fertilizers (F2). Data also indicated that cropping patterns $\times$ nutrient management treatments interactions were significant for nutrients uptake by maize. Thus, the highest values of $\mathrm{N}, \mathrm{P}$ and $\mathrm{K}$ uptake were reported in plots, which sowing with maize intercropped with cowpea and received the half dose of recommended chemical fertilizers+organic manure (compost) $30 \mathrm{~m}^{3} \mathrm{ha}^{-1}$ +Biofertilizers (Table 9). Whereas, plots sowing with maize/millet intercropping pattern and received the half dose of recommended chemical fertilizers+organic manure (compost) $30 \mathrm{~m}^{3} \mathrm{ha}^{-1}+$
Biofertilizers (F4), recorded the highest values of $\mathrm{Fe}, \mathrm{Zn}$ and Mn uptake by maize (Table 9).

\section{Discussion}

From the data in the current study, it could be noted that, in general the data of the second season were higher than those of the first season. These interactions might have been due to the differences in meteorological parameters between the two seasons. Furthermore, results also showed that maize plants in intercropping system has higher vigor with good health than mono-cropping system, such superiority of maize growth in intercropping system may be due to optimum growth condition, which allowed plants to take their nutrient requirements and also make full use of light and water, thereby plants had a good chance to expressed their genetic constituents and produced maximum growth performances. In line with this finding, Hamd Alla et al. (2014), Luli et al. (2016) and Kimou et al. (2017), reported that intercropping system increased plant height of maize compared to mono-cropping system. Contrary, the experiments of Mohammed et al. (2010), Undie et al. (2012a,b) and Lemlem (2013) revealed that, there were no significant differences in terms of maize plant height when intercropped with soybean and cowpea, as compared to sole cropping system. As a result of yield and yield component characters, the current results are corroborates with the findings of $\mathrm{Wu}$ et al. (2012), Qin et al. (2013), Midega et al. (2014), Liu et al. (2017) and Wang et al. (2017a,b), they reported that yield advantages in maize plants when intercropped with cowpea as compared to corresponding sole crop system. These results are verified that different plant species grown in the same time at the same area, are need to different ecological requirements and thus, the competition between neighboring plants for light, water and nutrients reduced or may be became in lower level or almost absence, hence maize could complementary utilize obtainable environmental resources. Additionally, several investigators stated that, yield advantages of intercropping systems compared with sole cropping system may be due to the increase in land use efficiency by more than $100 \%$ for intercropping than sole cropping system (Sharma \& Behera, 2009 ; Chen et al., 2014 and Yin et al., 2015). Earlier, HauggaardNielsen et al. (2001) reported that maize as a sole cropping system requires a more area to produce the same yield as in intercropping system. Prosper 
et al. (2017), concluded that intercropping of maize with legumes had the highest yield advantages with optimum exploitation of the land and environmental resources. In the same context, several investigators reported that, the superiority of intercropped maize/legume was expected, since biological nitrogen fixation by legumes, which is valued to maize growth and help to maintain highest grain yield and improve soil fertility (Kheroar \& Patra, 2014 and Ashish et al., 2015). Unlike, the present results are in contrast with the findings of (Chakma et al., 2011; Lemlem, 2013; Kheroar \& Patra, 2014 and Kimou et al., 2017), they reported that the maximum grain yield was obtained from sole cropping system, while the lower grain yield was maintained for intercropped maize/ cowpea, meanwhile results in the current study of intercropped maize/millet are in line with the previous studied and recorded the lower value of biological yield (ton ha ${ }^{-1}$ ) and grain yield (ton $\mathrm{ha}^{-1}$ ), such effect may be related to both crops are $\mathrm{C} 4$ photosynthetic pathways and nearly has the same requirements, thus the competition between neighboring plants was higher. Kheroar \& Patra (2014), also reported that maize yield in intercropping system with cereal was reduced due to receipt of lower amount of growth requirements and/or the combation between the same plant species. Such results are linked with the fact that, photosynthetic pathways of crops with C4 plants have been known to be dominant when intercropped with $\mathrm{C} 3$ species.

Regarding the effect of managing nutrient supplies, the current results indicated that the largest advantages in plant height, yield and yield component characters were noticed in plots, which plants were received nutrients in integrated forms, even at a partial dose of the recommended synthetic fertilizers, for example half dose of chemical fertilizers+organic manure $30 \mathrm{~m}^{3} \mathrm{ha}^{-1}+$ Biofertilizers, followed by application of half dose of chemical fertilizers+organic manure $30 \mathrm{~m}^{3} \mathrm{ha}^{-1}$. These results are supported the previous findings, which is stated that application of organic manure in combination with adequate mineral fertilizers, able to compensate the reduction in the dose of chemical fertilizers, even the reduction equal to the half dose of the recommended. Such effect may be due to application fertilizers in integration organic and inorganic sources, can offer good option and economic choice to supplies plants with sufficient nutrient requirements for long time (Khan et al., 2010; Suge et al., 2011; Ali et al., 2012; Dejene \& Lemlem, 2012; Laekemariam \& Gidago, 2012; Ghulam et al., 2015 and Selim \& Al-Owied, 2017). Also, Achieng et al. (2010), reported that application fertilizers in different organic sources, can improved physiochemical soil properties and thereby increased the movement and the uptake of NPK in sandy calcareous soils and increased the productivity of wheat and grain sorghum. Moreover, application nutrients in organic form can easily absorbed by plant roots after they react in the soil and changed to a form, which are readily available by plant roots (Anonymous, 2009). However, inoculation seeds with biofertilizers, can increased the population of different bacteria species in the rhizosphere, hence increased microbial stimulation effect and constructed sustainable supplies with essential nutrients, which are necessary for plant growth through gradual mineralization, fixation and mobilization (Song et al., 2007; Garbeva et al., 2008; Samreen et al., 2017 and Wang et al., 2017a,b). Additionally, the experiments of Zuo et al. (2000), Song et al. (2007) and Li et al. (2014) suggested that, the advantages in yield and yield components characters by rhizobium inoculation is thought to be mainly due to the increase of rhizobia structure community in rhizosphere . Data in Tables 6 and 8 also cleared that sole application of the half dose of chemical fertilizers reduced yield and yield component characters of maize as compared to application of full dose of chemical fertilizers . Such decrement probably due to lower nutrient availability, which are insufficient to meet the requirements of maize growth.

Concerning the interactions, the recent results revealed that there is a strong positive correlation between intercropped maize with cowpea and received half dose of chemical fertilizers +organic manure $30 \mathrm{~m}^{3} \mathrm{ha}^{-1}+$ biofertilizers (F4), exceeding all experimental treatments and recorded the highest values of plant height and yield as well as yield component characters. Iqbal et al. (2012), Rahman et al. (2013), came to similar conclusion, they suggested that intercropping cereal/legume cropping system in combination with bio-organic farming system and or with adequate nutrient supplies in poor soil fertility can be successfully compensate low productivity and mitigates the soil nutrients deficit. In the same context, the experiments of Chandrakala et al. (2017) 
concluded that, following intercropping practices alongside integrated nutrient management could be supplied plants with its nutrient requirements and mitigate the harmful effect of the absence of essential nutrients. Such practice can overcomes one of the serious problems accompanying the excessive applications of synthetic fertilizers, which is usually followed by many farmers.

The successes of nutrient use by plants is defined by several ways, among these, determining plant nutrients content, especially in those, which are grown under stress or in soils which has nutrient problems. Accordingly, the superiority of intercropped maize/cowpea in terms of nitrogen uptake may be explained by the ability of cowpea, as legume crop, to biological nitrogen fixation and provide maize with sufficient amount of $\mathrm{N}$, in addition the competition between neighboring plants for nutrients absorption was completely absent. In addition, the presences of enough amount of nitrogen in rhizosphere affected on all other nutrients, improved root elongation and increased the availability of insoluble inorganic elements in soil like phosphorus and potassium uptake (Long et al., 2006). Furthermore, the effect of intercropping systems of cereal/cereal species is clearly observed in terms of increasing the uptake of $\mathrm{Fe}, \mathrm{Mn}$ and $\mathrm{Zn}$, this may be explained by the ability of gramineous species to excretion of phytosiderophores (PS) into the rhizosphere, which act with unavailable form of $\mathrm{Fe}$ and $\mathrm{Zn}$ and transport (PS Fe) or (PS-Zn) from the rhizosphere to the root cell for uptake (Inal et al., 2007; Zuo \& Zhang, 2009, 2011 and Marschner et al., 2012).

Results of managing nutriment requirements of maize grown in different cropping systems in calcareous soil are strongly demonstrate the importance of integrated use of inorganic, organic and biofertilizers sources in fertilization programs. The superiority of integrated nutrients management can be explained by nutrients required by maize is provided through the chemical fertilizers, addition of organic manures and biofertilizers improved physiochemical soil properties and could able to sustainably supplies plants with essential nutrients (Zuo \& Zhang, 2011; Verlinden et al., 2011 and Seyfollah et al., 2014). Whereas, the positive effects of interaction between cropping patters $\mathrm{x}$ managing nutriments can be clarified by the effect of each factor individually.

\section{Conclusion}

Nutrient deficiencies are the most common yieldlimitation and low productivity. It is well known that, calcareous soils are characterized by low organic matter, high $\mathrm{pH}(7.5-8.5)$ and high levels of bicarbonate. Therefore, plants under such condition suffered from some nutrient problems, and soil health problems, which are not only an agronomic issue, but also strongly related to social issues, especially for poor farmers, which they are unable to spend large investments in maintaining soil fertility. Occasionally, intercropping systems may be the best way or dominant option for complementarily utilize ecological resources. In addition, adopts cropping system cereal/ legume alongside integrated nutrient management (Supplementary part of inorganic fertilizers by organic manure and biofertilizers) is a most effective practices can prevent nutrients deficiency and a pragmatic approach by considering totality of the farm wastes that can be used as plant nutrients.

\section{References}

Achieng, J.O., Ouma, G., Odhiambo, G. and Muyekho, F. (2010) Effect of farmyard manure and inorganic fertilizers on maize production on alfisols and ultisols in Kakamega, western Kenya. Agric. Biol. J. N. Am. 1, 430-439.

Adeoye, P.A., Adebayo, S.E. and Musa, J.J. (2011) Growth and yield response of cowpea (Vigna unguiculata) to poultry and cattle manure as amendments on sandy loam soil plot. Agric. J. 6(5), 218-221.

Ali, M., Ali, A., Tahir, M. and Yaseen, M. (2012) Growth and yield response of hybrid maize through integrated phosphorus management. Pakistan. Journal of Life Social Science, 10, 59-66.

Ashish, D., Ista, D., Vineet, K., Rajveer, S.Y., Mohit, Y., Dileep, G., Adesh, S. and Tomar, S.S. (2015) Potential role of maize-legume intercropping systems to improve soil fertility status under smallholder farming systems for sustainable agriculture in India. Interl. J. Life Sci. Biotech. Pharma Res. 4, 3.

Anonymous (2009) "25 Years of Pulses Research at IIPR", Shiv Kumar and Mohan Singh (Ed.), pp.1984-2009. Published by: Indian Institute of Pulses Research, Kanpur 208024, India. 
Bhattacharyya, R., Chandra, S., Singh, R.D., Kundu, S., Srivastva, A.K. and Gupta, H.S. (2007) Long term farmyard manure application effects on properties of a silty clay loam soil under irrigated wheatsoybean rotation. Soil and Tillage Research, 94, 386-396.

Bremner, J.M. (1996) Total nitrogen. In: "Methods of Soil Analysis", Part 3, D.L. Sparks (Ed.), pp. 10851122. Madison, Wisc: SSSA and ASA.

Boschetti, N.G., Quintero, C.E. and Giuffre, L. (2009) Phosphorus fractions of soils under Lotus corniculatus as affected by different phosphorus fertilizers. Biol. Fertil. Soils, 45, 379-384.

But, R. (2004) "Soil Survey: Laboratory Manual Report", No.42 USDA, National Resources Conservation Service. Washington.

Caviglia, O.P., Sadras, V.O. and Andrade, F.H. (2011) Yield and quality of wheat and soybean in sole- and double-cropping. Agronomy Journal, 103, 10811089.

Chandrakala, M., Srinivasamurthy, Sanjeev, Kumar, C.A. and Naveen, D.V. (2017) Effect of application of graded level of phosphorus to finger millet-maize cropping system in soils of different $\mathrm{P}$ fertility. International Journal of Current Microbiology and Applied Sciences, 6(11), 265-280. http://www. ijcmas.com

Chakma, R., Aziz, M.A., Rahman, A.K.M.M, Khatun, M.F. and Sultana, M. (2011) Intercropping popcorn with bushbean and pea at different planting systems in hill valley areas. J. Exp. Biosci. 2(2), 35-38.

Chen, H., Qin, A., Chai, Q., Gan, Y. and Liu, Z. (2014) Quantification of soil water competition and compensation using soil water differences between strips of intercropping. Agric. Res. 3, 321-330.

Cottenie, A. (1982) Soil and plant testing as a basis of fertilizer recommendations. FAO Soils Bulletin $38 / 2$.

Dejene M. and Lemlem M. (2012) Integrated agronomic crop managements to improve teff productivity under terminal drought. In: "Water Stress", I. Md. M. Rahman and H. Hasegawa (Ed.), In Tech Open Science. 12, 236-254 (Accessed 25, January, 2012).

Donohue, S.J. and Aho, D.W. (1992) Determination of $\mathrm{P}, \mathrm{K}, \mathrm{Ca}, \mathrm{Mg}, \mathrm{Mn}, \mathrm{Fe}, \mathrm{Al}, \mathrm{B}, \mathrm{Cu}$ and $\mathrm{Zn} \mathrm{In}$ plant tissue by inductively coupled plasma (ICP) emission spectroscopy. In Plant analysis reference procedures for the southern United States (Southern Cooperative Series Bulletin 368), C.O. Plank (Ed.), pp.34-37. Athens: University of Georgia.

Donohue, S.J., Brupbacher, R.H., Isaac, R.A., Landcaster, J.D., Mehlich, A. and Scott, D.D. (1983) Reference soil test methods for the southern region of the United States (Southern Cooperative Series Bulletin 289). Athens: University of Georgia.

FAO Statistical Yearbook (2012) "World Food and Agriculture". $1^{\text {st }}$ ed, pp. 36. Stylus Pub Llc. ISBN10: 9251070849.

Garbeva, P., van Elsas, J.D. and van Veen, J.A. (2008) Rhizosphere microbial community and its response to plant species and soil history. Plant Soil, 302,19-32.

Ghulam, R., Anwar, J.W., Muhammad, N. and Momna, A.R. (2015) Determination and evaluation of the effect of different doses of humic acid on the growth and yield of wheat (Triticum aestivum L.). IOSR Journal of Agriculture and Veterinary Science (IOSR-JAVS), 8(2), Ver. I: 05-07.

Gomez, K.A. and Gomez, A. (1984) "Statistical Procedures for Agricultural Research", $2^{\text {nd }}$ ed. John Wiley \& Sons, New York.

Gudugi, IAS (2013) Effects of cow dung and variety on the growth and yield of Okra (Abelmuschus esculentus L.), European Journal on Experimental Biology, 3(2), 495-498.

Haigang, Li, Jianbo, S. and Zhang, F. (2010) Phosphorus uptake and rhizosphere properties of intercropped and monocropped maize, faba bean, and white lupin in acidic soil. Biol. Fertil. Soils, 46, 79-91.

Hamd Alla, W.A., Shalaby, E.M., Dawood, R.A. and Zohry, A.A. (2014) Effect of Cowpea (Vigna sinensis L.) with Maize (Zea mays L.) intercropping on yield and its components. Int. J. Biol. Biomed. Agric. Food Biotechnol. Eng. 8(11), 1258-1264.

Hauggaard-Nielsen, H., Ambus, P. and Jensen, E.S. (2001) Interspecific competition, $\mathrm{N}$ use and interference with weeds in pea-barley intercropping. Field Crops Research, 70, 101-109. 
Inal, A., Gunes, A., Zhang, F.S. and Cakmak, I. (2007) Peanut/maize intercropping induced changes in rhizosphere and nutrient concentrations in shoots, Plant Physiol. Bioch. 45, 350-356.

Iqbal Muhammad, A.Gh.Kh., Anwar, U.L., Hassan, W.R.M. and Muhammad, A. (2012) Soil organic carbon, nitrate contents, physical properties and maize growth as influenced by dairy manure and nitrogen rates. Int. J. Agric. Biol. 14, 1, 20-28.

Janzen, H.H. (1993) Soluble salts. In: "Soil Sampling and Methods of Analysis", M.R. Carter (Ed.), pp. 161-166. Boca Raton, Fl.: Lewis Publishers.

Jannoura, R., Joergensen, R.G. and Bruns, C. (2014) Organic fertilizer effects on growth, crop yield, and soil microbial biomass indices in sole and intercropped peas and oats under organic farming conditions. European Journal of Agronomy, 52, 259-270.

Jones, J.B. and Case, V.W. (1990) Sampling, handling, and analyzing plant tissue samples. In: "Soil Testing and Plant Analysis", Westerman (Ed.), pp.389-427, Soil Sci. Soc. Am. Madison WI. 3.

Kacar, B. and Katkat, A. (2009) Plant nutrition/ Nobel publication No. 843/Science and Biology publication Series No. 29-Ankara, Turkey- 424-533.

Kaya, M., Zeliha, K. and Erdal, I. (2009) Effects of elemental sulfur and sulfur containing waste on nutrient concentrations and growth of bean and corn plants grown on a calcareous soil. Afr. J. Biotechnol. 8(18), 4481-4489.

Khan, S., Hesham, A.E.L., Qiao, M., Rehman, S. and He, J.Z. (2010) Effects of $\mathrm{Cd}$ and $\mathrm{Pb}$ on soil microbial community structure and activities. Environ. Sci. Pollut. Res. 17, 288-296. doi: 10.1007/ s11356-009-0134-4.

Kheroar, S. and Patra, C.B. (2014) Productivity of maize-legume intercropping systems under rain fed situated situation. Afr. J. Agric. Res. 9(20), 16101617.

Kimou, S.H., Coulibaly, L.F., Koffi, B.Y., Toure, Y., Dedi, K.J. and Kone, M. (2017) Effect of row spatial arrangements on agromorphological responses of maize (Zea mays L.) and cowpea (Vigna unguiculata L.). African Journal of Agricultural Research, 12(34), 2633-2641.
Laekemariam, F. and Gidago, G. (2012) Response of maize (Zea mays L.) to integrated fertilizer application in Wolaita. South Ethiopia. Advances in Life Science and Technology, 5, 21-30.

Lemlem, A. (2013) The effect of intercropping maize with cowpea and lablab on crop yield. Herald $J$. Agric. Food Sci. Res. 2(5), 156-170.

Li, C.J., Li, Y.Y., Yu, C.B., Sun, J.H., Christie, P. and An, M. (2011) Crop nitrogen use and soil mineral nitrogen accumulation under different crop combinations and patterns of strip intercropping in northwest China. Plant and Soil, 342, 221-231.

Li, L., Zhang, L.Z. and Zhang, F.Z. (2013) Crop mixtures and the mechanisms of over yielding. In: "Encyclopedia of Biodiversity", Levin, S.A. (Ed.), $2^{\text {nd }}$ ed., Vol, 2, pp. 382-395. Waltham, MA, USA: Academic Press.

Li, L., Tilman, D., Lambers, H. and Zhang, F.S. (2014) Biodiversity and over yielding: insights from below-ground facilitation of intercropping in agriculture. New Phytologist, 203, 63-69.

Liu, L., Wang, Y.F., Yan, X.W., Li, J.W., Jiao, N.Y. and $\mathrm{Hu}$, S.J. (2017) Biochar amendments increase the yield advantage of legume-based intercropping systems over monoculture. Agric. Ecosyst. Environ. 237, 16-23.

Long, Li, Shu-Min, Li, Jian-Hao, Sun, Li-Li, Z., XingGuo, B., Hong-Gang, Z. and Fu-Suo, Z. (2007) Diversity enhances agricultural productivity via rhizosphere phosphorus facilitation on phosphorusdeficient soils. Freely available online through the PNAS open access option.

Luli, B., Worku, W. and Beyene, S. (2016) Determinations of haricot bean (Phaseolus vulgaris L.) planting density and spatial arrangement for staggered intercropping with maize (Zea mays L.) at Wondo Genet, Southern Ethiopia. Acad. Res. J. Agric. Sci. Res. 4(6), 297-320.

Lv, Y., Francis, C., Wu, P.T., Chen, X.L. and Zhao, X.N. (2014) Maize-soybean intercropping interactions above and below ground. Crop Science, 54, 914-922.

Marschner, P. (Ed.) (2012) "Mineral Nutrition of Higher Plants", $3^{\text {rd }}$ ed. Waltham, MA, USA: Academic Press. 
Mao, L.L., Zhang, L.Z., Zhao, X.H., Liu, S.D., Van der Werf, W. and Zhang, S.P. (2014) Crop growth, light utilization and yield of relay intercropped cotton as affected by plant density and a plant growth regulator. Field Crops Research, 155, 67-76.

Mc Dowell, R.W., Condron, L.M. and Stewart, I. (2008) An examination of potential extraction methods to assess plant-available organic phosphorus in soil. Biol. Fertil. Soils, 44, 707-715.

Midega, C.A.O., Salifu, D., Bruce, T.J., Pittchar, J., Pickett, J.A. and Khan, Z.R. (2014) Cumulative effects and economic benefits of intercropping maize with food legumes on Striga hermonthica infestation. Field Crops Research, 155, 144-152.

Mohammed, A., Diko, A.U., Adua, M. and Sigha, A. (2010) Comparative effects of cow pea and soybean genotype on nitrogen fixation and nitrogen balance in Sokata Dry sub Humid agro ecological zone of Nigeria.www.2j01.info/index.php/njbas/article/ dawnload/64346/52139.

Motior Rahman, M., Abdou Soaud, A., Fareed, H., AL Darwish Faruq, G. and Sofian- Azirun, M. (2011) Growth and nutrient uptake of maize plants as affected by elemental sulfur and nitrogen fertilizer in sandy calcareous soil. African Journal of Biotechnology, 10(60), 12882-12889.

Nelson, D.W. and Sommers, L.F. (1982) Total carbon, organic carbon, and organic matter. In: "Methods of Soil Analysis", Page, A.L., Miller, R.H. and Keeney, D.R. (Ed.), Part 2, $2^{\text {nd }}$ ed., pp. 565-571. Madison, Wisc: ASA and SSSA.

Paltridge, N.G., Coventry, D.R., Tao, J., Heath, T.J. and Tash, N. (2014) Intensifying grain and fodder production in Tibet by using cereal-forage intercrops. Agronomy Journal, 106, 337-342.

Prosper, I., Massawel, K.M., Mtei, L.K. and Patrick, A.N. (2017) Economic benefits of maize and legume (common bean and dolichos lablab) intercrop as influenced by rhizobial inoculation. ARPN Journal of Agricultural and Biological Science, 12(4), 133-143.

Qin, A.Z., Huang, G.B., Chai, Q., Yu, A.Z. and Huang, P. (2013) Grain yield and soil respiratory response to intercropping systems on arid land. Field Crops Res. 144, 1-10.
Rahman, M.H., Islam, M.R., Jahiruddin, M., Rafii, M.Y., Hanafi, M.M. and Malek, M.A. (2013) Integrated nutrient management in maize-legumerice cropping pattern and its impact on soil fertility. Journal of Food, Agriculture \& Environment, 11 (1), 648-652.

Rahmann, G., Ardakani, M.R., Bàrberi, P., Böhm, H., Canal, S., Chander, M., David, M., Dengel, L., Erisman, J.W., Galvis-Martinez, A.C., Hamm, U., Kahl, J., Köpke, U., Kühne, S., Lee, S.B., Loes, A.K., Moos, J.H., Neuhoff, D., Nuutila, J.J. and Oppermann, R. et al. (2016) Organic agriculture 3.0 is innovation with research. Organic Agriculture, DOI 10.1007/ s13165-016-0171-5.

Recep İrfan, N., Alpaslan, K., İlker, Inal and Veyis, T. (2015) Effects of different organic materials on forage yield and nutrient uptake of silage maize (Zea mays L.). Journal of Plant Nutrition, 39, 912-921.

Samreen, S., Zahir, S. and Wisal, M. (2017) Impact of organic amendments on soil carbon sequestration, water use efficiency and yield of irrigated wheat. Biotechnol. Agron. Soc. Environ. 21(1).

Sarwar, G., Hussain, N., Schmeisky, H. and Muhammad, S. (2007) Use of compost an environment friendly technology for enhancing rice-wheat production in Pakistan. Pakistan Journal of Botany, 39(5), 1553-1558.

Sarwar, G., Hussain, N., Schmeisky, H., Muhammad, S., Ibrahim, M. and Safdar, E. (2008) Improvement of soil physical and chemical properties with compost application in rice-wheat cropping system. Pakistan Journal of Botany, 40(1), 275-282.

Selim, M.M. and Al-Owied, Al-Jawhara A. (2017) Genotypic responses of pearl millet to integrated nutrient management. Bioscience Research, 14(2), 156-169.

Seyfollah, F. and Amir-Ghalavand, F.R. (2014) The combined influence of broiler litter and mineral NP fertilizers on soil chemical properties, maize performance and nutrient uptake in a calcareous soil. Report and Opinion, 6(7), 15-20.

Sharma, A.R. and Behera, U.K. (2009) Recycling of legume residues for nitrogen economy and higher productivity in maize (Zea mays)-wheat (Triticum aestivum) cropping system. Nutr. Cycl. Cropping Syst. 83, 197-210. 
Siavoshi, M., Nasiri, A. and Laware, S.L. (2011) Effect of organic fertilizer on growth and yield components in rice (Oryza sativa L.). J. Agric. Sci. 3(3), 217-224. doi:10.5539/jas.v3n3p217.

Song, Y.N., Zhang, F.S., Marschner, P., Fan, F.L., Gao, H.M., Bao, X.G., Sun, J.H. and Li, L. (2007) Effect of intercropping on crop yield and chemical and microbiological properties in rhizosphere of wheat (Triticum aestivum L.), maize (Zea mays L.) and faba bean (Vicia faba L.). Biol Fertil. Soil, 43, 565-574.

Suge, J.K., Omoniyi, M.E. and Omani, E.N. (2011) Effect of organic and inorganic sources of fertilizer on growth, yield and fruit quality of eggplant (Solanum melongena). Achieves of Applied Science Research, 3(6), 470-479.

Tewolde, H., Sistani, K.R., Rowe, D.E., Adeli, A. and Johnson, J.R. (2007) Lint yield and fiber quality of cotton fertilized with broiler litter. Agronomy Journal, 99, 184-194.

Undie, U.L., Uwah, D.F. and Attoe, EE. (2012a) Effect of intercropping and crop arrangement on yield and productivity of late season maize/ soybean mixtures in the humid environment of South Southern. Nigeria. Journal of Agricultural Science, 4(4), 37-50.

Undie, U.L., Uwah, D.F. and Attoe, E.E. (2012b) Growth and development of late season maize/ soybean intercropping in response to nitrogen and crop arrangement in the Forest Agro-ecology of South Southern Nigeria. Inter. J. Agric. Res. 7(1), $1-16$.

Verlinden, K.L., Thompson, D.W.J. and Stephens, G.L. (2011) The three-dimensional distribution of clouds over the Southern Hemisphere high latitudes. J. Climate, 24, 5799-5811. doi:10.1175/2011JCLI3922.1.

Wang, D., Marschner, P., Solaiman, Z. and Rengel, Z. (2017a) Belowground interactions between intercropped wheat and Brassicas in acidic and alkaline soils. Soil Biol. Biochem. 39, 961-971.
Wang, Y.Q., Zhao, Z.G., Li, J.P., Zhang, M., Zhou, S.L., Wang, Z.M. and Zhang, Y.H. (2017b) Does maize hybrid intercropping increase yield due to border effects? Field Crop. Res. 214, 283-290.

Wu, K.X., Fullen, M.A., An, T.X., Fan, Z.W., Zhou, F. and Xue, G.F. (2012) Above- and below-ground interspecific interaction in intercropped maize and potato: A field study using the 'target' technique. Field Crops Research, 139, 63-70.

Yin, W., Yu, A.Z., Chai, Q., Hu, F.L., Feng, F.X., Gan, Y.T. (2015) Wheat and maize relay-planting with straw covering increases water use efficiency up to 46\%. Agron. Sustain. Dev. 35, 815-825.

Yolcu, H., Şeker, H., Gullap, M.K., Lithourgidis, A. and Güneş, A. (2011) Application of cattle manure, zeolite and leonardite improves hay yield and quality of annual ryegrass (Lolium multiflorum Lam.) under semiarid conditions. AJCS, 5, 926-931.

Zomer, R.J., Trabucco, A., Coe, R. and Place, F. (2009) Trees on farm: analysis of global extent and geographical patterns of agroforestry. ICRAF Working Paper no. 89. Nairobi, Kenya: World Agroforestry Centre.

Zuo, Y. and Zhang, F. (2009) Iron and zinc biofortification strategies in dicot plants by intercropping with gramineous species. A review. Agronomy for Sustainable Development, Springer Verlag/EDP Sciences/INRA, 29(1), 63-71. https:// hal.archives-ouvertes.fr/hal-00886491.

Zuo, Y.M., Zhang, F.S., Li, X.L. and Cao, Y.P. (2000) Studies on the improvement in iron nutrition of peanut by intercropping maize on a calcareous soil, Plant Soil, 220, 13-25.

Zuo, Y.M. and Zhang, F.S. (2011) Effect of peanut mixed cropping with gramineous species on micronutrient concentrations and iron chlorosis of peanut plants grown in a calcareous soil. Plant Soil, 306, 23-36.

(Received 19/11/2018; accepted 25/12/2018) 
دور نظم الزراعة والإدارة المتكاملة للمغذيات على امتصاص العناصر الغذائية والأستفادة منها فى الأرة المزروعة في تربة جيرية

قسم بحوث المحاصيل الحقلية ـ المركز القومي للبحوث ـ الدقى ـ القاهرة ـ مصر.

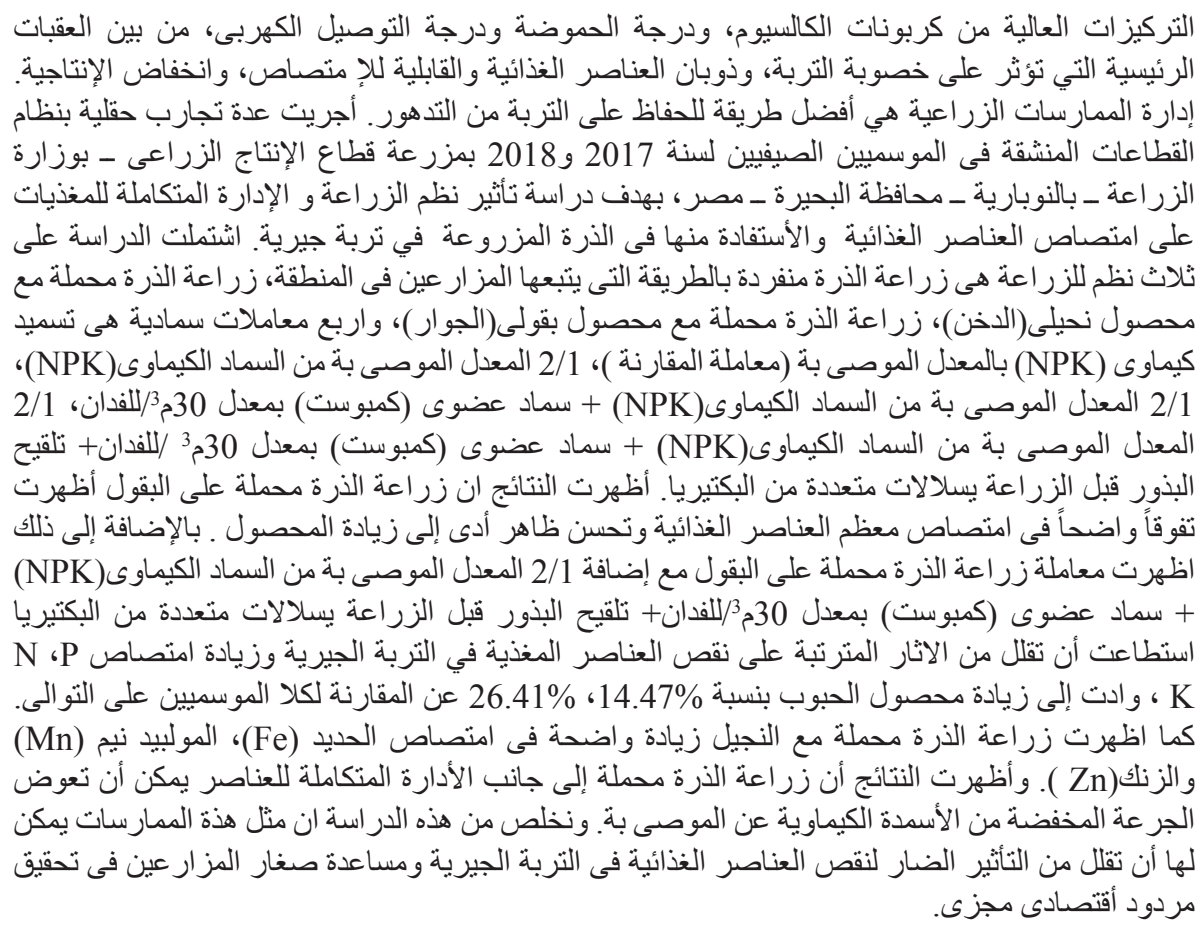

